\title{
Human milk and preterm formula compared for effects on growth and metabolism
}

\author{
O G BROOKE, O ONUBOGU, R HEATH, AND N D CARTER \\ Department of Child Health, St George's Hospital Medical School, London
}

SUMmaRY Metabolic tolerance to a 'premature formula' feed was studied in a group of small immature infants, mean (SD) gestation $27 \cdot 8(1.4)$ weeks. Ten infants weighing $880-1295 \mathrm{~g}$ at the time of the study were fed on SMA low birthweight formula for a mean (SD) of $23 \cdot 5(5 \cdot 5)$ days and were compared with 10 who were fed on expressed breast milk for $25 \cdot 8(6 \cdot 1)$ days. The infants were well matched for weight, gestation, and postnatal age at the time of the study and were receiving full enteral feeds. They were investigated by balance techniques and plasma sampling on at least two occasions. Ten larger infants weighing 1330-1740 g and being fed on the same formula feed were also studied as an additional control group. Formula fed infants retained more nitrogen and gained weight faster. Plasma phosphorus concentrations were higher in the group fed on the formula feed, and alkaline phosphatase activity was lower. There were no significant differences in plasma concentrations of urea, electrolytes, or albumin or in acid base status. Taurine and arginine concentrations were higher in the group being breast fed, but there were no other significant differences in plasma amino acids, and no toxic concentrations occurred after either feed. The results of this study show that this formula (and presumably other feeds of similar composition) seem to be metabolically safe for the smallest infants.

Preterm formula feeds have been in use in neonatal nurseries for some years, and there have been several reports assessing their effects on growth and metabolism. The smallest infants are vulnerable to the harmful effects of unsuitable feeding-for example, poor gastric emptying, milk bolus obstruction, ${ }^{1}$ metabolic acidosis, ${ }^{2}$ hypertyrosinaemia, ${ }^{3}$ and even necrotising enterocolitis. ${ }^{4}$ Nevertheless, data evaluating the effects of preterm formula feeds on these tiny infants are scanty and there is a reasonable reluctance, especially among neonatal nurses, to substitute such feeds for breast milk despite the known nutritional disadvantages of breast milk for such babies; these include appreciable deficiencies in protein, sodium, calcium, and phosphorus. ${ }^{5-7}$ This paper reports an investigation into growth and metabolism in extremely immature infants who weighed $<1300 \mathrm{~g}$ on entry to the study, in which a preterm formula feed (SMA low birthweight formula) was compared with expressed breast milk.

\section{Patients and methods}

Infants. Thirty seven infants were recruited into the study, but this analysis describes 20 infants matched for weight, gestation, and postnatal age. Ten were fed the formula feed and 10 expressed breast milk (EBM); a further 10 larger infants fed on formula feed acted as an additional control group. It was planned that the low weight infants should all weigh $<1250 \mathrm{~g}$ at the time of the study, but because of the continued need for intravenous hydration in some, the design was modified to include infants between 1250 and $1300 \mathrm{~g}$ as well. Because infants suitable for such a study are rarely available in large numbers the final number studied was dictated by constraints of time and money rather than by formal examination of the power of the study to discriminate between the groups in respect of the variables associated with outcome. We attached special importance to obtaining enough infants to allow proper matching of weight, age, and gestation in two feeding groups of reasonable size. All suitable infants admitted to the neonatal unit at this hospital during the period of study were recruited, providing their parents agreed. Criteria of suitability were that there was no major malformation, no need for continued ventilation or intravenous feeding, and no important additional factors present (such as a 
patent ductus arteriosus or major intraventricular haemorrhage) that might limit growth. Infants were nursed in thermoneutrality, and none received theophyllines during the period of the study.

Feeding. Initial enteral feeding was with breast milk (either maternal or banked EBM), and the infants entered the study when they tolerated $180 \mathrm{ml} / \mathrm{kg} /$ day. At this time infants whose mothers wanted to continue providing breast milk were allocated to remain on EBM and formed the breast milk control group. Infants whose mothers did not wish to provide milk were allocated to the formula group. Because of the high rate of breast feeding at this hospital 27 infants fed on breast milk were recruited before 10 could be recruited to be fed on the formula. Table 1 gives details of these 10 and of the 10 with whom they were matched who were fed with EBM. Ten larger infants (weighing 1330-1740 $\mathrm{g}$ at the start of the study) were also fed with SMA formula feed to serve as a control for the group weighing $<1300 \mathrm{~g}$ when the various metabolic criteria were investigated; Table 2 gives details of these babies. The EBM group received fresh maternal breast milk supplemented as necessary with pasteurised banked breast milk (usually $\leqslant 25 \%$ ) and with sodium chloride (to maintain plasma sodium concentrations above $130 \mathrm{mmol} / \mathrm{l}$ ), phosphorus ( $25 \mathrm{mg}$ as buffered sodium phosphate daily), calcium (65 mg as calcium lactate/gluconate daily), and vitamin D (600 IU daily). The formula fed group received no other form of nutrition except supplementary vitamin D. Table 3 gives the macronutrient composition of SMA low birthweight formula together with the protein and energy content of the EBM.

The mean (SD) length of the study period for the formula fed group was $23.5(5.5)$ days and for the EBM group $25 \cdot 8(6 \cdot 1)$ days. The study was approved by the hospital ethical committee.

Measurements of growth. All infants were weighed daily on a calibrated Marsden spring balance (Marsden Weighing Machines, London W9) accurate to within $5 \mathrm{~g}$. Crown-heel length was measured twice a week to the next succeeding $1.0 \mathrm{~mm}$ on a neonatal

Table 1 Details of infants studied weighing $<1300 \mathrm{~g}$

\begin{tabular}{|c|c|c|c|c|c|c|c|c|}
\hline \multirow[t]{2}{*}{$\begin{array}{l}\text { Case } \\
\text { No }\end{array}$} & \multicolumn{2}{|c|}{$\begin{array}{l}\text { Birth weight } \\
(g)\end{array}$} & \multicolumn{2}{|c|}{$\begin{array}{l}\text { Gestation } \\
\text { (weeks) }\end{array}$} & \multicolumn{2}{|c|}{$\begin{array}{l}\text { Age at start } \\
\text { of study (days) }\end{array}$} & \multicolumn{2}{|c|}{$\begin{array}{l}\text { Weight at start } \\
\text { of study }(\mathrm{g})\end{array}$} \\
\hline & $S M A$ & $E B M$ & $S M A$ & $E B M$ & $S M A$ & $E B M$ & $S M A$ & $E B M$ \\
\hline 1 & 1170 & 1200 & 28 & 27 & 14 & 20 & 1180 & 1170 \\
\hline 2 & 1010 & 990 & 27 & 28 & 35 & 25 & $12(x)$ & 1140 \\
\hline 3 & 950 & 960 & 25 & 26 & 22 & 16 & 990 & 955 \\
\hline 4 & 1175 & 1100 & 30) & 29 & 12 & 22 & 1290 & 1280 \\
\hline 5 & 900 & 900 & 28 & 29 & 12 & 10 & 880 & 890 \\
\hline 6 & 970 & 890 & 27 & 27 & 27 & 29 & 1160 & 1050 \\
\hline 7 & 1100 & 1160 & 27 & 28 & 15 & 10 & 1190 & 1070 \\
\hline 8 & 890 & 880 & 29 & 29 & 12 & 12 & 880 & 910 \\
\hline 9 & 1330 & 1260 & 29 & 30 & 12 & 12 & 1270 & 1290 \\
\hline 10 & 1140 & 850 & 28 & 26 & 26 & 40) & 1295 & $13(0)$ \\
\hline Mean & 1064 & 1019 & $27 \cdot 8$ & $27 \cdot 9$ & 19 & 20 & 1134 & 1106 \\
\hline SD & 143 & 149 & 1.4 & 1.4 & 8 & 10) & 159 & 156 \\
\hline
\end{tabular}

Table 2 Details of infants studied weighing $\geqslant 1300 \mathrm{~g}$ fed on formula feed

\begin{tabular}{|c|c|c|c|c|}
\hline $\begin{array}{l}\text { Case } \\
\text { No }\end{array}$ & $\begin{array}{l}\text { Birth weight } \\
\text { (g) }\end{array}$ & $\begin{array}{l}\text { Gestation } \\
\text { (weeks) }\end{array}$ & $\begin{array}{l}\text { Age at start } \\
\text { of study (days) }\end{array}$ & $\begin{array}{l}\text { Weight at start } \\
\text { of study (g) }\end{array}$ \\
\hline 1 & 850 & 26 & 44 & 1330) \\
\hline 2 & 1230 & 28 & 27 & $14(x)$ \\
\hline 3 & 1480 & 30 & 14 & $14(x)$ \\
\hline 4 & 1520 & 30 & 5 & 1410 \\
\hline 5 & 1380 & 31 & 12 & 1510 \\
\hline 6 & 1300 & 32 & 11 & 1550 \\
\hline 7 & 1180 & 26 & 37 & 1550 \\
\hline 8 & 1350 & 31 & 15 & 1560 \\
\hline 9 & 940 & 26 & 47 & 1710 \\
\hline 10 & 1480 & 29 & 25 & 1740) \\
\hline Mean & 1271 & 28.9 & 24 & 1516 \\
\hline SD & 227 & $2 \cdot 3$ & 15 & 135 \\
\hline
\end{tabular}


Table 3 Composition of feeds (constituents per litre)

\begin{tabular}{lll}
\hline & $\begin{array}{l}\text { SMA low } \\
\text { birthweight formula }\end{array}$ & EBM \\
\hline Mean (SD) energy (kJ) & 3344 & $3118(38) \dagger$ \\
Mean (SD) protein (g) & 20 & $13 \cdot 7(0 \cdot 3)$ \\
Whey: casein & $60: 40$ & \\
Fatł (g) & 44 & $\mathrm{NM}$ \\
Carbohydrate (g): & 43 & $\mathrm{NM}$ \\
$\quad$ Lactose & 43 & $\mathrm{NM}$ \\
Maltodextrin & 320 & $\mathrm{NM}$ \\
Sodium (mg) & 750 & $\mathrm{NM}$ \\
Potassium (mg) & 530 & $\mathrm{NM}$ \\
Chloride (mg) & 750 & $\mathrm{NM}$ \\
Calcium (mg) & 400 & $\mathrm{NM}$ \\
Phosphorus (mg) & 5 & $\mathrm{NM}$ \\
Zinc (mg) & $0 \cdot 7$ & $\mathrm{NM}$ \\
Copper (mg) & 268 & \\
Osmolality (mmol/kg) & & \\
\hline
\end{tabular}

${ }^{*}$ Manufacturer’s data. †Gross energy. $\Varangle$ Beef fat, vegetable oils, $10 \%$ medium chain triglyceride. NM Not measured.

stadiometer. Occipitofrontal head circumference and mid-upper arm circumference were measured twice a week to the next succeeding $1.0 \mathrm{~mm}$ with a paper tape measure. Upper arm and lower leg lengths were also measured twice a week to the next succeeding $1.0 \mathrm{~mm}$ with a caliper. ${ }^{8}$ Triceps and subscapular skinfold thicknesses were measured twice a week to the next succeeding $0.1 \mathrm{~mm}$ with a Harpenden caliper. ${ }^{9}$ All anthropometric measurements except weight were done by the same trained person $(\mathrm{OO})$, whose variation in multiple determinations did not exceed $5 \%$ of the mean for any measurement.

Measurement of feeds. All feeds were given by nasogastric tube. Volume of intake was measured and carefully recorded for each infant. During balances all regurgitations were collected on preweighed pads and their weight, converted to volume, was subtracted from the intake.

Measurement of balances. Two energy and nitrogen balances were performed for each infant, separated by one to two weeks. Before and after the balances, which lasted three days, a carmine marker was given. All stools passed between the markers were collected in napkin liners ${ }^{10}$ and immediately frozen at $-24^{\circ} \mathrm{C}$. They were later weighed, freeze dried, weighed again, homogenised, and analysed for energy by bomb calorimetry, ${ }^{11}$ for fat by the gravimetric technique, using the Soxtec apparatus, and for nitrogen by the Kjeldahl technique, using the Kjeltec apparatus. The Soxtec and Kjeltec systems were devised by Tecator AB, Box 70, S-263 01, Höganäs, Sweden, and based on the Soxhlet gravimetric fat assay and Kjeldahl nitrogen assay. Urine was collected in preweighed, disposable nappies free of nitrogen, ${ }^{10}$ sealed in plastic bags at each nappy change, and immediately frozen at $-24^{\circ} \mathrm{C}$. The nappies were later reweighed to obtain urine volume and then washed in a known volume of water. After filtering, aliquots were freeze dried and analysed for energy and nitrogen. During one of the three day balance periods urine was collected for 24 hours on ice by continuous aspiration using a perineal bag and a small electric pump. ${ }^{12}$ This urine was also analysed for nitrogen and energy. All analyses were done without knowing which type of feed the infant was having.

Representative samples of breast milk and a single sample of formula (which had a constant composition) were analysed for energy and nitrogen, and these values were used in the balance calculations.

Biochemical measurements. Weekly measurements were made of plasma concentrations of urea, sodium, potassium, bicarbonate, calcium, and phosphorus with an autoanalyser. Alkaline phosphatase activity and plasma amino acid concentrations were measured fortnightly with an LKB 4400 amino acid analyser (LKB Biochrom Ltd, Cambridge Science Park, Cambridge, England). Blood gas tensions were measured weekly from a capillary sample.

Statistical analysis. All data were normally distributed, and the significance of the differences was calculated with Student's $t$ test.

\section{Results}

Infants $<1300 \mathrm{~g}$ : SMA low birthweight formula feed $v$ EBM. Tables 1 and 2 show that the groups were comparable for birth weight, gestation, and age and weight at the time of the study.

\section{Feed intake}

Intake during the two balance periods (total six days) was representative of the overall intake during the study period. Infants receiving SMA low birthweight formula feed received a mean (SD) of 606 (105) $\mathrm{kJ} / \mathrm{kg}$ daily and $598(85) \mathrm{mg}$ nitrogen $/ \mathrm{kg}$. Infants receiving EBM received $602(134) \mathrm{kJ} / \mathrm{kg}$, and 424 (97) $\mathrm{mg}$ nitrogen $/ \mathrm{kg}$. Table 3 gives the protein and energy contents of the EBM.

\section{Macronutrient digestion and retention}

Table 4 gives the data for energy and protein digestibility and retention. Digestibility is defined as energy or nitrogen intake minus faecal energy or nitrogen losses $\times 100(\%)$ energy or nitrogen intake. Retention is defined as digestible energy or nitrogen $(\mathrm{kJ}$ or $\mathrm{mg} / \mathrm{kg}$ ) minus urinary losses of energy or 
Table 4 Mean (SD) macronutrient digestion and retention

\begin{tabular}{|c|c|c|c|c|c|}
\hline & \multirow{2}{*}{$\begin{array}{l}E B M \\
\text { Infants } \\
<1300 \mathrm{~g}\end{array}$} & & \multicolumn{3}{|c|}{ SMA low birthweight formula feed } \\
\hline & & & $\begin{array}{l}\text { Infants } \\
<1300 \mathrm{~g}\end{array}$ & & $\begin{array}{l}\text { Infants } \\
\geqslant 1300 \mathrm{~g}\end{array}$ \\
\hline Energy digestibility (\%) & $77 \cdot 3(8 \cdot 5)$ & NS & $78 \cdot 5(5 \cdot 4)$ & NS & $81 \cdot 0(6 \cdot 0)$ \\
\hline Protein digestibility (\%) & $86 \cdot 1(5 \cdot 9)$ & $\begin{array}{l}t=2 \cdot 1 \\
\mathrm{p}=(0 \cdot 04\end{array}$ & $81 \cdot 6(4 \cdot 8)$ & $\begin{array}{l}t=2 \cdot 5 \\
\mathrm{p}=0 \cdot(02\end{array}$ & $86 \cdot 2(3 \cdot 1)$ \\
\hline Metabolisable energy $(\mathrm{kJ} / \mathrm{kg} /$ day $)$ & 427 (117) & NS & $490(80)$ & NS & $494(54)$ \\
\hline Nitrogen retention $(\mathrm{mg} / \mathrm{kg} /$ day $)$ & $221(90)$ & $\begin{array}{l}t=3.0 \\
\mathrm{p}=0.006\end{array}$ & $337(114)$ & NS & $404(62)$ \\
\hline
\end{tabular}

nitrogen $(\mathrm{kJ}$ or $\mathrm{mg} / \mathrm{kg})$, expressed as a daily retention rate in $\mathrm{kJ}$ or $\mathrm{mg} / \mathrm{kg}$.

Protein digestibility was greater $(p=0.04)$ in babies fed on breast milk than in those fed on the formula feed, but nitrogen retention was considerably greater $(p=0.006)$ in those fed the formula feed. No significant difference in metabolisable energy intake was found between the two groups, but the mean in the formula group was $63 \mathrm{~kJ} / \mathrm{kg} /$ day greater than the mean in the group fed on breast milk.

\section{Growth}

Table 5 shows a comparison of the data about growth. Weight gain was significantly greater in the formula fed infants $(p=0.003)$ with the difference averaging nearly $9 \mathrm{~g} / \mathrm{kg} /$ day. Growth of the subscapular fat fold was also significantly greater in the formula fed group $(p=0 \cdot 02)$. The growth rates of triceps fat fold and mid-upper arm circumference did not differ between the groups.

No significant differences were found in linear growth or head size between the two groups.

\section{Metabolism}

Table 6 shows the results of the measurements of plasma $\mathrm{pH}$, base excess, concentrations of urea, electrolytes, albumin, calcium, and phosphorus, and

Table 5 Mean (SD) anthropometric measurements during growth in infants fed on EBM and formula

\begin{tabular}{|c|c|c|c|c|}
\hline & \multirow{2}{*}{$\begin{array}{l}E B M \\
<1300 g\end{array}$} & \multirow{2}{*}{$\begin{array}{l}\text { Significance } \\
\text { of difference }\end{array}$} & \multicolumn{2}{|c|}{ SMA low birthweight formula feed } \\
\hline & & & $<1300 \mathrm{~g}$ & $\geqslant 1300 \mathrm{~g}$ \\
\hline Weight gain ( $\mathrm{g} / \mathrm{kg} /$ day) & $136(3 \cdot 6)$ & $\begin{array}{l}t=3 \cdot 5 \\
\mathrm{p}=0) \cdot(003\end{array}$ & $22 \cdot 1(6 \cdot 3)$ & $17 \cdot 3(3 \cdot 1)$ \\
\hline \multicolumn{5}{|l|}{ Length gain ( $\mathrm{mm} /$ day) } \\
\hline Crown-heel & $1 \cdot 22(0 \cdot 52)$ & NS & $1.02(0.54)$ & $1.70(0.22)$ \\
\hline Upper arm & $0.21(0.16)$ & NS & $0.36(0 \cdot 19)$ & $0.38(0.18)$ \\
\hline Lower leg & $0.32(0.12)$ & NS & $0.40(0.25)$ & $0.42(0.19)$ \\
\hline \multicolumn{5}{|c|}{ Circumferential growth ( $\mathrm{mm} /$ day) } \\
\hline Head & $1.47(0 \cdot 18)$ & NS & $1.97(0.77)$ & $1.31(0.74)$ \\
\hline Mid-upper arm & $0.67(0.23)$ & NS & $0.58(0.23)$ & $0.61(0.22)$ \\
\hline \multicolumn{5}{|c|}{ Fat fold measurements $(\mathrm{mm} /$ week $)$} \\
\hline Triceps & $0 \cdot 16(0 \cdot 30)$ & NS & $0.46(0.36)$ & $0.32(0.29)$ \\
\hline Subscapular & $0.17(0.21)$ & $\begin{array}{l}t=2 \cdot 4 \\
\mathrm{p}=0.02\end{array}$ & $0.39(0 \cdot 15)$ & $0.31(0.25)$ \\
\hline
\end{tabular}

Table 6 Mean (SD) of biochemical measurements

\begin{tabular}{|c|c|c|c|c|}
\hline & \multirow{2}{*}{$\begin{array}{l}E B M \\
<1300 g\end{array}$} & \multirow{2}{*}{$\begin{array}{l}\text { Significance } \\
\text { of difference }\end{array}$} & \multicolumn{2}{|c|}{ SMA low birthweight formula feed } \\
\hline & & & $<1300 \mathrm{~g}$ & $\geqslant 1300 \mathrm{~g}$ \\
\hline Urea $(\mathrm{mmol} / \mathrm{l})$ & $1.85(0.92)$ & NS & $1.58(0.87)$ & $1.81(1.02)$ \\
\hline Sodium $(\mathrm{mmol} / \mathrm{l})$ & $136 \cdot 3(5 \cdot 2)$ & NS & $134 \cdot 6(3 \cdot 6)$ & $138 \cdot 1(3 \cdot 7)$ \\
\hline Potassium $(\mathrm{mmol} / \mathrm{l})$ & $5.07(1 \cdot 13)$ & NS & $4.91(0.90)$ & $5 \cdot 20(0 \cdot 71)$ \\
\hline Albumin $(g / 1)$ & $30(3)$ & NS & $32(8)$ & $33(7)$ \\
\hline Calcium $(\mathrm{mmol} /)$ & $2.62(0.23)$ & NS & $2 \cdot 29(0 \cdot 21)$ & $2 \cdot 22(0 \cdot 12)$ \\
\hline Phosphorus (mmol/l) & $1.56(0.43)$ & $\begin{array}{l}t=2.9 \\
\mathrm{p}=0.01\end{array}$ & $2 \cdot 15(0.44)$ & $1.87(0.42)$ \\
\hline Alkaline phosphatase (IU/I) & $504(241)$ & $\begin{array}{l}t=2 \cdot 2 \\
\mathrm{p}=0.036\end{array}$ & $301(107)$ & $431(140)$ \\
\hline pH of capillary blood & $7 \cdot 31$ & NS & $7 \cdot 28$ & $7 \cdot 30$ \\
\hline Base excess $(\mathrm{mmol})$ & -4 & & -5 & -4 \\
\hline
\end{tabular}


alkaline phosphatase activity made after two weeks in the two groups. The only significantly different findings were a lower plasma phosphorus concentration in the breast fed group $(p<0.01)$ and higher alkaline phosphatase activity $(\mathrm{p}=0.036)$.

The figure shows the results of estimations of amino acid concentrations in plasma. In formula fed infants taurine and arginine concentrations were lower than those in the breast fed group $(p<0.05)$, but there were no other significant differences. Table 7 shows the highest measured concentrations of certain selected amino acids which may be potentially toxic. In the formula fed group the highest values were all from one infant (birth weight $970 \mathrm{~g}$, age at sampling 14 days). In the EBM group the highest values were found in three different infants.

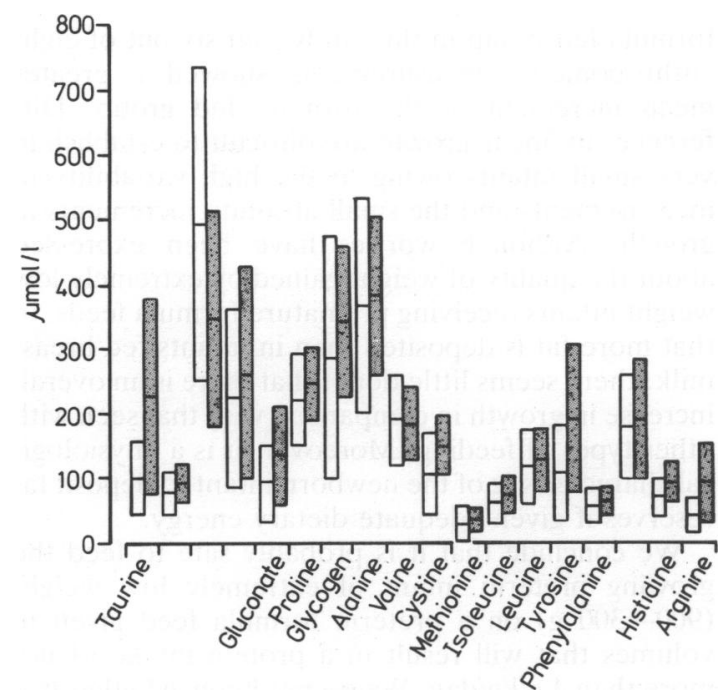

Figure Plasma aminogram in formula fed infants $\square \square$ and those fed on breast milk Values are means $(S D)$.

Table 7 Highest measured concentrations of selected amino acids in infants weighing $<1300 \mathrm{~g}$ fed $E B M$ and SMA low birthweight formula (umolll)

\begin{tabular}{lcc}
\hline Amino acids & EBM & $\begin{array}{l}\text { SMA low birthweight } \\
\text { formula feed }\end{array}$ \\
\hline Methionine & 70 & 88 \\
Tyrosine & 393 & 258 \\
Phenylalanine & 105 & 115 \\
Histidine & 160 & 130 \\
Proline & 313 & 328 \\
Valine & 290 & 323 \\
Leucine & 230 & 210 \\
Isoleucine & 123 & 105 \\
\hline
\end{tabular}

Infants $\geqslant 1300 \mathrm{~g}$ fed on SMA low birthweight formula. Tables 4-6 show details of food intake, digestibility, growth rates, and biochemical variables in the larger infants. These infants digested protein more easily $(p=0.02)$, but retention of nitrogen, and amount of energy metabolised were not significantly different from those in the other groups. The larger infants gained marginally less weight $(17.3 \vee 22.1 \mathrm{~g} / \mathrm{kg} /$ day $)$, but there were no substantial differences in the biochemical variables with the exception of the amino acids; concentrations of hydroxyproline, glycine, and arginine were all significantly higher in the larger babies $(p<0.05)$. Although no significant difference was found for any other amino acid, the mean value for every amino acid except taurine was higher in the larger than the smaller infants. When all amino acids were considered together the mean value was significantly greater in the larger babies $(\mathrm{p}<0 \cdot 01)$.

\section{Discussion}

Concern over the metabolic consequences of feeding a relatively high protein intake to preterm infants has not been borne out by the results of this study. ${ }^{213}$ Even the smallest infants receiving premature formula feed achieved plasma concentrations of potentially toxic amino acids that were well within the limits of probable safety ${ }^{14}$ and were no higher than those reached by those fed on breast milk. ${ }^{14}$ The importance of differences in plasma amino acid concentrations between infants of such immaturity is not yet known. It would be of concern if the branched chain amino acids were particularly low in any feed given to an infant who should be growing, because this pattern is one of the features of kwashiorkor, ${ }^{15}$ but this was not the case in any of the infants in our study. It would also be of concern if any infant showed abnormally high concentrations of those amino acids that may be toxic, but this was not the case either, and there were no significant differences in $\mathrm{pH}$, base excess, or blood urea concentration to suggest that the formula fed infants were in metabolic difficulty compared with the breast fed infants.

The lack of important differences between the two groups in these respects may reflect the relatively high protein concentrations that are achieved in preterm breast milk, ${ }^{6}{ }^{16-18}$ although we cannot confirm this because we did not monitor the protein content of our EBM throughout the study. A formula consisting mainly of whey, however, with a protein concentration of about $2.0 \mathrm{~g} / 100 \mathrm{ml}$ would be unlikely to cause toxic effects due to inadequate protein metabolism in infants as small as $900 \mathrm{~g}$, provided they were growing. This proviso is import- 
ant because the ill or poorly growing infant who is unwell may be unable to use dietary proteins adequately, and there is no guarantee that under such conditions potentially dangerous metabolic effects will not occur. It is also unwise to increase the volume of enteral feed in the immature infant until tolerance is adequate and the infant is growing.

We did not expect the larger infants to have higher concentrations of amino acids than the smaller. Examination of the data showed a higher mean feed intake in the larger infants together with greater net nitrogen retention, and this probably accounted for the differences in the concentrations of amino acids.

Arginine and taurine concentrations were lower in formula fed infants. There is no clinical disadvantage in having low plasma concentrations of arginine, though arginine synthetase activity is reduced in the fetus and low plasma concentrations might indicate deficiency. ${ }^{19}$ Arginine may protect the low birthweight infant from high dietary amino acid loads, perhaps through increased turnover in the urea cycle, so there is a theoretical reason for suggesting that the intake of arginine should be greater than that provided by present formulas. ${ }^{20}$ Taurine is an important constituent of bile salts in infants fed on human milk, and when formulas based on cows' milk (which are low in taurine) are used the bile acids are predominantly conjugated by glycine. This has given rise to concern that function of bile salts might be impaired when feeds low in taurine are used, but supplementation of such feeds with taurine has no effect on fat absorption in preterm infants. ${ }^{21}$ Taurine is an essential nutrient, and the prolonged use of diets lacking in taurine causes retinal damage in cats. ${ }^{22}$ The amount of taurine required in the diet to prevent such abnormalities is certainly very small, and no lesions suggestive of taurine deficiency have ever been described to our knowledge in preterm or full term infants fed on formulas based on cows' milk. All the infants in our study who were fed on the formula had measurable concentrations of taurine in the plasma, so it seems unlikely that it is necessary to supplement such formulas with taurine. A larger series of analyses of amino acid concentrations in the plasma of infants of low birthweight fed on the same formula failed to show significant differences in arginine or taurine when compared with a group fed on breast milk, though there were significant differences in concentrations of other amino acids. ${ }^{23}$

The data on calcium and phosphorus concentrations lend support to the view that breast milk is an inadequate source of phosphorus and should be supplemented. ${ }^{74-26}$ The higher phosphorus content of the preterm formula feed ensures a normal plasma phosphorus concentration in most infants and significantly lower alkaline phosphatase activity. Metabolic bone disease of prematurity is seen less commonly in infants fed on preterm formula feeds, and later linear growth is better. ${ }^{7}$ The immature and rapidly growing infant needs a lot of phosphorus; adequate calcium retention will not occur without it, and in severe phosphorus depletion all the cellular mechanisms that produce energy will be impaired. ${ }^{27-29}$

The results of the balances confirm that a well designed formula feed achieves adequate macronutrient digestibility: there was no significant difference between the formula feed and breast milk in energy absorption and only a small reduction in protein absorption. Nitrogen retention and mean metabolisable energy intake were higher in those babies fed on the formula, and this was reflected in their greater weight gain. We were unable to show significant increases in linear growth or head growth in the formula fed group in this study, but six out of eight anthropometric measurements showed a greater mean increment in the formula fed group. Differences in linear growth are difficult to establish in very small infants owing to the high variability in measurements and the small absolute increments in growth. Although worries have been expressed about the quality of weight gained by extremely low weight infants receiving premature formula feeds, in that more fat is deposited than in infants fed breast milk, there seems little doubt that there is an overall increase in growth in comparison with that seen with other types of feeding. Moreover, it is a physiological characteristic of the newborn infant to deposit fat reserves if given adequate dietary energy.

We conclude that it is probably safe to feed the growing preterm infant of extremely low weight $(900-1300 \mathrm{~g})$ on a preterm formula feed given in volumes that will result in a protein intake of not more than $4 \mathrm{~g} / \mathrm{kg} /$ day. We do not know whether it is wise to begin using such formulas in the early days, but perhaps it is prudent to start enteral feeding with a feed of relatively low nutrient density. Undigested food residues may well be important in the pathogenesis of necrotising enterocolitis, and gastric emptying in preterm infants is considerably slower when they are fed on formulas high in protein than when they are fed on expressed breast milk. It seems sensible, therefore, to begin enteral feeding in the smallest infants with breast milk and to introduce a premature formula feed only when the infant has established reliable gastric emptying and has begun to gain weight.

References
' Brooke OG, Gentner PR, Harzer G, Spitz L. Milk fat bolus 
obstruction in a preterm infant. Acta Paediatr Scand 1982;71:691-2.

2 Räihä NCR, Heinonen K. Rassin DK, Gaull GE. Milk protein quality and quantity in low-birth-weight infants: 1. Metabolic responses and effects on growth. Pediatrics 1976;57:659-74.

${ }^{3}$ Kretchmer N, Levine SZ, McNamara $H$. The in vitro metabolism of tyrosine and its intermediates in the liver of the premature infant. Am J Dis Child 1957:93:19-29.

+ Goldman HI. Feeding and necrotising enterocolitis. Am J Dis Child 1980;134:533-6.

${ }^{5}$ Brooke OG. Nutrition in the preterm infant. Lancet 1983;i: 514-5.

6 Lucas A, Hudson GJ. Preterm milk as a source of protein for low birthweight infants. Arch Dis Child 1984:59:831-6.

${ }^{7}$ Brooke OG, Lucas A. Metabolic bone disease in preterm infants. Arch Dis Child 1985;60:682-5.

${ }^{\star}$ Brooke OG, Butters F, Wood C, Bailey P, Tukmachi F. Size at birth from 37-41 weeks gestation: ethnic standards for British infants of both sexes. J of Human Nutrition 1981;35:415-30.

${ }^{9}$ Tanner JM, Whitehouse RH. Revised standards for triceps and subscapular skinfolds in British children. Arch Dis Child 1975;50:142-5.

10 Brooke OG, Alvear J, Arnold M. Energy retention, energy expenditure and growth in healthy immature infants. Pediatr Res 1979:13:215-20.

1 Miller DS, Payne PR. A ballistic bomb calorimeter. Br J Nutr 1965;13:501-3.

12 Lyon AJ, McIntosh N. Calcium and phosphorus balance in extremely low birthweight infants in the first six weeks of life. Arch Dis Child 1984:59:1145-50.

13 Rassin DK, Gaull GE, Räihä NCR, Heinonen K. Milk protein quantity and quality in low birthweight infants: IV. Effects on tyrosine and phenylalanine in plasma and urine. $J$ Pediatr 1977;90:356-65,391-422.

${ }^{14}$ Rohr FJ, Levy HL, Shih VE. Inborn errors of metabolism. In: Walker WA, Watkins JB, eds. Nutrition in pediatrics. Boston: Little, Brown \& Co. 1985.

15 Whitehead RG. Rapid determination of some plasma amino acids in subclinical kwashiorkor. Lancet 1964;i:250-1.

16 Atkinson SA, Bryan MH, Anderson GH. Human milk: difference in nitrogen concentration in milk from mothers of term and premature infants. J Pediatr 1978;93:67-9.

17 Schanler RJ, Oh W. Composition of breast milk obtained from mothers of premature infants as compared to breast milk obtained from donors. J Pediatr 1980;96:679-81

${ }^{18}$ Griss SJ, David JR, Bauman L. Tomarelli RM. Nutritional composition of milk produced by mothers delivering preterm. J Pediatr 1980;96:641-4.

19 Räihä NCR. Quantity and quality of milk protein intake: metabolic response in the neonate. Klin Padiatr 1985:197:176-8.

20) Pohlandt F. Studies of the requirement of amino acids in newborn infants receiving parenteral nutrition. In: Visser HKA. ed. Nutrition and metabolism of the foetus and infant. Amsterdam: Martinus Nijhoff, 1979:341-540.

21 Watkins JB, Järvenpää A-L, Szczepanik V-LP, et al. Feeding the low birthweight infant: effects of taurine, cholesterol and human milk on bile acid kinetics. Gastroenterology 1983;85: 793-802.

22 Hayes KC. Carey RE, Schmidt SY. Retinal degeneration associated with taurine deficiency in the cat. Science 1975:188:949-51.

23 Ventura V, Brooke OG. Plasma amino acids in infants of low birth weight. Arch Dis Child (in press).

${ }^{24}$ Senterre J, Putet G. Salle B, Rigo J. Effects of vitamin D and phosphorus supplementation on calcium retention in preterm infants fed banked human milk. J Pediatr 1983:203:305-10.

25 Salle B. Senterre J. Putet G. Rigo J. Effects of calcium and phosphorus supplementation on calcium retention and fat absorption in preterm infants fed pooled human milk. J Pediatr Gastroenterol Nutr 1986:5:638-43.

26 Rowe J. Rowe D. Horak E. et al. Hypophosphatemia and hypercalciuria in small premature infants fed human milk: evidence for inadequate dietary phosphorus. $J$ Pediatr 1984;204:112-6.

27 Jacob HS, Amsden T. Acute hemolytic anemia with rigid red cells in hypophosphatemia. N Engl J Med 1971;287:1446-50.

${ }^{28}$ Prins JC, Schryver H. Staghouer JH. Hyperalimentation. hypophosphatemia, and coma. Lancet 1973:i:1253-4.

${ }^{24}$ Juan D. The causes and consequences of hyperphosphatemia. Surg Gynecol Obstet 1981:153:589-97.

Correspondence to Dr N D Carter, Department of Child Health, St George's Hospital Medical School. London SW17 0RE.

Received 11 March 1987 